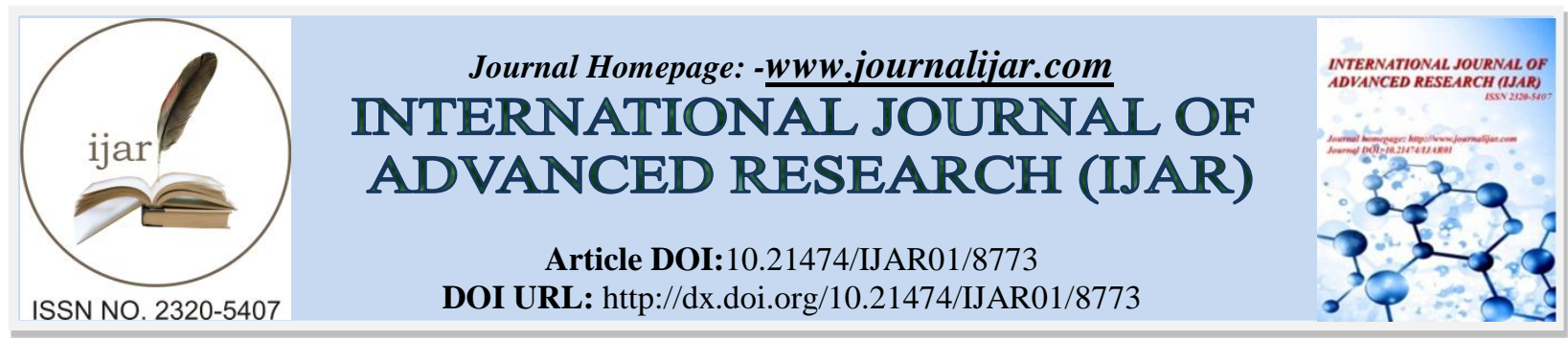

RESEARCH ARTICLE

\title{
PREVALENCE AND RISK FACTORS OF POSTPARTUM DEPRESSION AMONG WOMEN IN KINGDOME OF SAUDI ARABIA.
}

Nuseibah Saleh Mesleh Almakhalfi, Fadyah Mohammed Ayed Alradaddi, Raghad Abdullah Abdalmohsen Almeshari, Rasha Saidan Zoman Alwberi Alshammri and Abeer Hassan Elhaj .

\section{Manuscript Info}

Manuscript History

Received: 20 January 2019

Final Accepted: 22 February 2019

Published: March 2019

\section{Abstract}

Background: Postpartum depression (PPD) is more frequent in women than thought otherwise (2). The intensity of feeling inability in suffering mothers is so high that some mothers with postpartum depression comment life as the death swamp, while non depressed mothers see their baby's birth as the happiest stage of their life.

Aim: The present study aims to study the risk factors of postpartum depression among mothers.

Methods: Around 2090 Saudi women of postpartum period, were included and assessed using standardized questionnaire and predictive index of postnatal depression, to find out risk factors.

Results: The study found that the risk of developing postnatal depression was remarkably associated with the number of children which is increased with more than 5 children and positive family history as well. While no association between unplanned pregnancies and postpartum depression.

Conclusion: These risk factors can be ascertained during routine pregnancy care; therefore, it is important that antenatal healthcare providers and women themselves should educated about risk factors so that early identification of high risk women can be possible by closer follow-up.

Copy Right, IJAR, 2019,. All rights reserved.

\section{Introduction:-}

Over the past four decades, many studies have emphasized the importance of mood disorders after childbirth (1). Postpartum depression (PPD) is more frequent in women than thought otherwise (2). The intensity of feeling inability in suffering mothers is so high that some mothers with postpartum depression comment life as the death swamp, while non depressed mothers see their baby's birth as the happiest stage of their life.[3] The disease manifests as sleep disorders, mood swings, changes in appetite, fear of injury, serious concerns about the baby, much sadness and crying, sense of doubt, difficulty in concentrating, lack of interest in daily activities, thoughts of death and suicide.[4,5] Feelings of hopelessness in severe cases of illness can threaten life and lead to suicide;[6] it is a factor that causes $20 \%$ of maternal deaths in the course after giving birth.[7] In addition, issues such as fear of harming the baby (36\%), weak attachment to the baby (34\%) and even, in extreme cases, child suicide attempts have been reported.[8] These symptoms have serious effects on family health Therefore, susceptible people need to be identified before delivery to receive proper care measures. However, the development of screening programs as well as designing evidence-based prevention programs requires principled collection of scientific documentations.

Corresponding Author:-Nuseibah Saleh Mesleh Almakhalfi. 
Mothers at risk are seldom identified during pregnancy or at the time of delivery. This occurs especially in developing countries, where psychological issues are mostly ignored (9). It should be noted that up to $80 \%$ of cases do not seek medical attention and thus, are not diagnosed by the respective specialists. (10) Unfortunately, little attention has been paid to this condition in terms of identification, diagnosis, and treatment.

\section{Methods:-}

This is a cross sectional study held in Kingdom of Saudi Arabia to find out the risk factors of postpartum depression among mothers. All participants must be Saudi, have been married and have children. A total of 2090 subjects who met the inclusion criteria were selected by convenience sampling method. Participants were assessed by a standardized questionnaire. Data was analyzed using Statistical Package for Social Sciences (SPSS) program. Informed consent was addressed during this study for ethical consideration.

\section{Results:-}

Out of the target population, 2099 respondents were studied for their depression status and risk factors during their previous postnatal periods. About the characteristics of respondents our study found that, the age ranged from 20-49 years with mean age 23.84 years. All women were married at the time of interview. Majority of the women (94.2\%) were living with their husbands. About two third of the respondents had planned pregnancies (62.8\%), the majority had single parities and a few of them took special care. Regarding employment status, working women represent $(58.9 \%)$ and not working represents $(41.1 \%)$. In term of income, about (34.6\%) of the women had monthly income more than 11000 riyals. Table 1. Education level of study group was estimated showing that most of participants were graduated represent $(75.5 \%)$. Fig 1 . In respect to number of children of participants, the study reported that, those who have only one represents $(23.1 \%)$, the majority have between 2-4 children represents $(48.9 \%)$. Fig 2 . The study found that prevalence of postpartum depression was 9.5\% through a structured clinical interview which included diagnostic criteria of depression. Past history of depression was present in (20\%), and the family history of depression was present in only $(7.3 \%)$. An increased risk of maternal depressive symptoms was remarkably associated with the number of children which is more with more than 5 children. ( $p$ value $0.001, p>0.05$ by one-way ANOVA). Another variable found to be associated with the PPD's symptoms was whether they were first-time mothers. This indicates that new mothers and those have more than 5 children were more likely to experience PPD. Tables $2 \& 3$. The family history is also a significant predictor, according to sig. value $(\mathrm{p}=0.001$, by Independent $\mathrm{t}$ test). This indicated that those who have positive family history were more likely to suffer from PPD than those who haven't. Table 4. Unplanned Pregnancy with respect to postpartum depression our statistical finding reflecting that there is no association between unplanned pregnancies and postpartum depression. $(p<0.186$.) Table 5 shows the results of independent $t$ test.

Table 1:-Respondents' characteristics

\begin{tabular}{|l|l|l|l|}
\hline Variable & Categories & Frequency & $\%$ \\
\hline \multirow{4}{*}{ Age } & Below 20 Years & 68 & 3.3 \\
\cline { 2 - 4 } & From 20 to 30 years & 709 & 33.9 \\
\cline { 2 - 4 } & From 31 to 40 & 812 & 38.9 \\
\cline { 2 - 4 } & From 41 to 50 & 501 & 24.0 \\
\hline \multirow{4}{*}{ Marital status } & Married & 1969 & 94.2 \\
\cline { 2 - 4 } & Divorced & 69 & 3.3 \\
\cline { 2 - 4 } & Widow & 52 & 2.5 \\
\hline \multirow{3}{*}{ Employment status } & Working & 1231 & 58.9 \\
\cline { 2 - 4 } & Not working & 859 & 41.1 \\
\hline \multirow{5}{*}{ Income } & Below 11000 & 1137 & 54.4 \\
\cline { 2 - 4 } & 11000 & 232 & 11.1 \\
\cline { 2 - 4 } & Above 11000 & 721 & 34.5 \\
\hline \multirow{2}{*}{ Twins } & No & 778 & 37.2 \\
\cline { 2 - 4 } & Yes & 1312 & 62.8 \\
\hline \multirow{2}{*}{ Special Care } & No & 1960 & 93.8 \\
\cline { 2 - 4 } & Yes & 130 & 6.2 \\
\cline { 2 - 4 } & No & 1913 & 8.5 \\
\cline { 2 - 4 } & Yes & & \\
\hline
\end{tabular}


Figure 1:-Education level of the participants

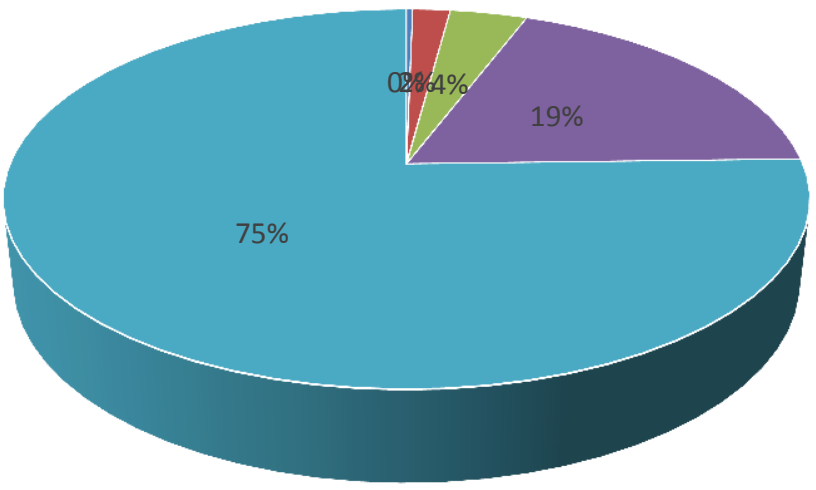

- Illiteracy - Primary - Intermediate - Secondary - Bachelor

Figure 2:-Number of Children of Participants

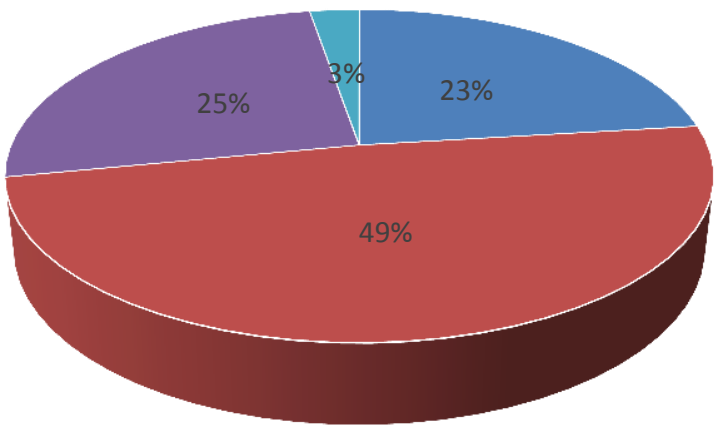

- 1 - 2 to 4 - 5 to 8 - Above 8

\section{Association between Number of Children and Postpartum Depression}

Table 2:-ANOVA results

\begin{tabular}{|l|l|l|l|l|l|}
\hline Test & Sum of Squares & df & Mean Square & F & Sig. \\
\hline Between Groups & 80.771 & 3 & 26.924 & 6.726 & .001 \\
\cline { 1 - 4 } Within Groups & 8350.330 & 2086 & 4.003 & & \\
\hline
\end{tabular}

$* \mathrm{p}<0.05$.

Table 3:-Multiple comparison post hoc

\begin{tabular}{|l|l|l|l|l|l|l|}
\hline $\begin{array}{l}\text { (I) Number Of } \\
\text { Delivery }\end{array}$ & $\begin{array}{l}\text { (J) Number } \\
\text { Of } \\
\text { Delivery }\end{array}$ & $\begin{array}{l}\text { Mean } \\
\text { Difference (I-J) }\end{array}$ & Std. Error & Sig. & \multicolumn{2}{l|}{$95 \%$ CI } \\
\cline { 5 - 7 } & & & & LP & UP \\
\hline 1 & $2-4$ & .19439 & .11055 & .294 & -.0899 & .4786 \\
\hline 1 & $5-8$ & $.46682^{*}$ & .12593 & .001 & .1430 & .7906 \\
\hline $2-4$ & Above 8 & $.88960^{*}$ & .28247 & .009 & .1633 & 1.6158 \\
\hline $2-4$ & $5-8$ & .27243 & .10710 & .054 & -.0029 & .5478 \\
\hline $5-8$ & Above 4 & .69521 & .27459 & .055 & -.0108 & 1.4012 \\
\hline
\end{tabular}

$* \mathrm{p}<0.05$. 
Association between Genetic Factor and Postpartum Depression

Table 4:-independent $t$ test results

\begin{tabular}{|l|l|l|l|l|l|}
\hline Test & $\mathrm{t}$ & $\mathrm{df}$ & $\mathrm{P}$ value & Mean Difference & $\begin{array}{l}\text { Std. } \\
\text { Difference }\end{array}$ \\
\hline $\begin{array}{l}\text { Equal variances not } \\
\text { assumed }\end{array}$ & -9.482 & 771.272 & $.001 *$ & -.95825 & .10106 \\
\hline
\end{tabular}

$* \mathrm{p}<0.05$.

Association between Unplaned Pregnancy and Postpartum Depression

Table 5:-independent $t$ test results

\begin{tabular}{|c|c|c|c|c|c|}
\hline Test & $\mathrm{t}$ & df & $\mathrm{P}$ value & Mean Difference & $\begin{array}{ll}\text { Std. } & \text { Error } \\
\text { Difference } & \\
\end{array}$ \\
\hline $\begin{array}{lll}\begin{array}{l}\text { Equal variances } \\
\text { assumed }\end{array} & \text { not } \\
\end{array}$ & 1.323 & 2088 & .186 & .12020 & .09089 \\
\hline
\end{tabular}

$* \mathrm{p}<0.05$.

\section{Discussion:-}

Out of the target population, 2099 respondents were studied for their depression status and risk factors during their previous postnatal periods. The present study revealed that the prevalence of Postpartum Depression was 9.5\%. The rate was lower than the prevalence estimated by EPDS that included studies from Danang City, Vietnam which found the PPD prevalence was 19.3\%. (11) With respect to unplanned Pregnancy and postpartum depression our statistical finding reflecting that there is no association between unplanned pregnancies and postpartum depression, while other research conducted in Pennsylvania found that there was association between them. (12) Regarding family history of depression, the study revealed that there was significant association between positive family history and post-natal depression which was the same as the study held in family of depression was present in only 7.3\%. Higher rate of family history of depression was found in Australia. (13). Also the same finding reflected by the study conducted in United States. (14) In our study we found that an increased risk of maternal depressive symptoms was remarkably associated with the number of children which is more with more than 5 children and also among women being mothers for the first time and that is differ than a study finding held in Isfahan which found there was no association between the number of deliveries and PPD or high parity and PPD. (15)

\section{Conclusion:-}

This study found factors like multigravida, women for first time being mothers and positive family history of postpartum depression, were significant predictors for postpartum depression. All of these potential risk factors can be ascertained during routine pregnancy care; therefore, it is important that antenatal healthcare providers and women themselves should educated about these risk factors so that early identification of high risk women and closer follow-up can be possible.

\section{Acknowledgements:-}

Authors would like to thank medical students at the College Of Medicine, King Saud Bin Abdulaziz University For Health Sciences, for their active contribution in the collection of data, Including Alaa Mohammed Alzamil, Nouf Hajaj Alharbi .

\section{References:-}

1. Lusskin SI, Pundiak TM, Habib SM. Perinatal depression: hiding in plain sight. Can J Psychiatry. 2007;52:47988. [PubMed]

2. Clay EC, Seehusen DA. A review of postpartum depression for the primary care physician. South Med J. 2004;97:157-61. [PubMed]

3. Beck CT, Records K, Rice M. Further development of the Postpartum Depression Predictors InventoryRevised. J Obstet Gynecol Neonatal Nurs. 2006;35:735-45. [PubMed]

4. Corwin EJ, Murray-Kolb LE, Beard JL. Low hemoglobin level is a risk factor for postpartum depression. J Nutr. 2003;133:4139-42. [PubMed]

5. Aswathi A, Rajendiren S, Nimesh A, Philip RR, Kattimani S, Jayalakshmi D, et al. High serum testosterone levels during postpartum period are associated with postpartum depression. Asian J Psychiatr. 2015;17:858. [PubMed] 
6. Norhayati MN, Hazlina NH, Asrenee AR, Emilin WM. Magnitude and risk factors for postpartum symptoms: A literature review. J Affect Disord. 2015;175:34-52. [PubMed]

7. Youn JH, Jeong IS. Predictive validity of the postpartum depression predictors inventory-revised. Asian Nurs Res (Korean Soc Nurs Sci) 2011;5:210-5. [PubMed]

8. Chaudron LH. Postpartum depression: What pediatricians need to know. Pediatr Rev. 2003;24:15461.[PubMed]

9. Halbreich U, Karkun S. Cross-cultural and social diversity of prevalence of postpartum depression and depressive symptoms. J Affect Disord. 2006;91:97-111. [PubMed]

10. Kelly RH, Russo J, Katon W. Somatic complaints among pregnant women cared for in obstetrics: normal pregnancy or depressive and anxiety symptom amplification revisited? Gen Hosp Psychiatry. 2001;23:10713. [PubMed]

11. O'Hara M, Swain A. Rates and risk of postpartum depression: a meta-analysis. Int Rev Psychiatry 1996; 8: 37 54.

12. Robertson E, Grace S, Wallington T, Stewart DE. Antenatal risk factors for postpartum depression: a synthesis of recent literature. Gen Hosp psychiatry 2004; 26: 289-295. 7

13. Cooper P.J, Murry L, Hooper R, West A. The development and validation of a predictive index for post partum depression. Psychological medicine, 1996: 26: 627-634.

14. American Psychiatric Association, Diagnostic and statistical manual of mental disorders, fourth edition, text revised. American Psychiatric Press, Washington, DC, 2000.

15. Asadi Sadeghi Azar I, Hashemi Z, Forghani F. Postpartum Depression and its Correlates among Women (Iran) Iran J Psychiatry. 2006;1:140-147. 